\title{
Gebelerde Prenatal Tanı Testlerinin ve Sonuçlarının Farkındalığı: Gaziantep'te Yapılan Kesitsel Bir Çalışma
}

\section{Awareness of Prenatal Diagnostic Tests and Outcomes in Pregnant Women: A cross-sectional Study in Gaziantep}

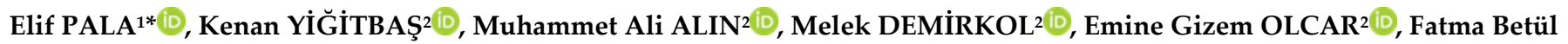

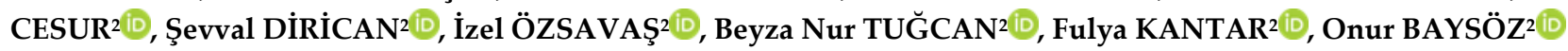

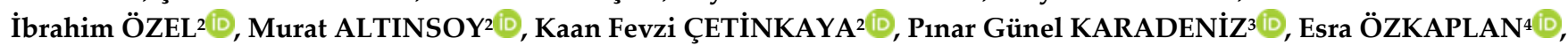 \\ Özlem SORAN ${ }^{5,6}$ (D)
}

\section{Atıf Yapmak İçin:}

Pala E, Yiğitbaş K, Alın MA, Demirkol M, Olcar EG, Cesur FB, Dirican Ş, Özsavaş I, Tuğcan BN, Kantar F, Baysöz O, Özel İ, Altınsoy M, Çetinkaya KF, Karadeniz PG, Özkaplan E, Soran Ö. Gebelerde prenatal tanı testlerinin ve sonuçlarının farkındalığı: Gaziantep'te yapılan kesitsel bir çalışma. Van Sag Bil Derg 2021, 14, (1): $1-6$.

https://doi.org/10.52976/van saglik.728371

Geliş Zamanı: 25/04/2020

Kabul Zamanı: 30/01/2021

Basılama Zamanı: 30/04/2021

\author{
SANKO Üniversitesi, T1bbi Biyoloji AD, Gaziantep, Türkiye \\ 2 SANKO Üniversitesi, Öğrenci, Gaziantep, Türkiye \\ 3 SANKO Üniversitesi, Biyoistatistik AD, Gaziantep, Türkiye \\ 4 SANKO Üniversitesi, Kadın Hastalıkları ve Doğum AD, Gaziantep, Türkiye \\ SANKO Üniversitesi, Kardiyoloji AD, Gaziantep, Türkiye \\ Pittsburgh University, Cardiovascular Institute, Pittsburgh, USA \\ * Sorumlu yazar: Elif PALA; E-mail: epala@sanko.edu.tr.
}

ÖZET

Giriş: Prenatal tanı; doğum öncesinde anne karnındaki fetüse ait örneklerde kromozom veya gen düzeyinde araştırma yapılması işlemidir. Bu çalışmada, Gaziantep'te gebelerin prenatal tanı testleri ve sonuçları hakkında farkındalık seviyesini değerlendirmek amaçlanmıştır.

Materyal ve Metot: Araştırmamıza SANKO Üniversitesi Sani Konukoğlu Hastanesi Uygulama ve Araştırma Merkezi, Kadın Hastalıkları ve Doğum Polikliniğine gebelik takibi amacı ile başvuran 500 kadın dâhil edilmiştir. Katılımcıların prenatal tanı testleri konusunda bilgi düzeyleri ve bu testlere yaklaşımı ile ilgili veriler, yüz yüze anket yöntemiyle toplanarak istatistiksel olarak değerlendirilmiştir.

Bulgular: Katılımcılardan daha önce prenatal tanı testlerinden birini yaptıranların oranı \%4.4 iken, \%17.2'si daha önce prenatal tanı testlerini duyduğunu ve hangi durumlarda yapıldığını bildiğini belirtmiştir. Doktorlarının prenatal tanı testlerinden birini önermesi hâlinde \%68.4'ü bu konuda bilgi sahibi olmadığı için önce araştırmayı, \%10'u ise yaptırmamayı tercih edeceklerini ifade etmiştir. Yaptırmamayı tercih edenlerin \%36.7'si sonucun gebelik devam kararında kendileri için önemsiz olacağını, \%32.6'sı düşük riskinden veya sonucun olumsuz olmasından korkacağını ve \%20.4'ü ise eşinin izin vermeyeceğini gerekçe göstermiştir. Bebeklerinde genetik olarak bir kusur tespit edilmesi hâlinde \%82.9'u gebeliklerine devam etmeyi seçeceklerini belirtmiştir. Tartışma: Çalışmamızın sonuçları Gaziantep'te prenatal tanı testleri konusundaki bilgi düzeyinin düşük olduğunu ve kadınların daha sağlıklı bir gebelik geçirebilmelerini sağlamak amacıyla konu ile ilgili geniş çaplı eğitim programlarının planlanmasının gerekliğini ortaya koymuştur.

Anahtar Kelimeler: Anket, Farkındalık, Prenatal tanı.

\section{ABSTRACT}

Objective: Prenatal diagnosis is the process of searching chromosomes orgenes in fetus samples before birth. The aim of this study was to evaluate the awareness and outcomes of prenatal diagnostic tests in prenant women in Gaziantep.

Materials and Methods: Five hundred women who applied to SANKO University Sani Konukoğlu Hospital Application and Research Center, Gynecology, and Obstetrics Clinic for pregnancy follow-up were included in the study. The level of knowledge about prenatal diagnostic tests and their approach to these tests were acqired by face-to-face questionnaire method and the data were evaluated statistically.

Results: While $4.4 \%$ of the participants had one of the prenatal diagnostic tests, $17.2 \%$ stated that they had heard prenatal diagnosis tests before and that they knew in what situations these tests were applied. If their physician recommends one of the prenatal diagnostic tests, $68.4 \%$ declared they would prefer to research first since they had noknowledge of it, and $10 \%$ said they would prefer not to do so. Of those who opted not to do so, $36.7 \%$ indicated that the outcome would be trivial in their decision to continue the pregnancy, $32.6 \%$ would fear the possibility of abortion or negative result, and $20.4 \%$ stated that their husband would not allow it. If a genetic defect would be detected in their babies, $82.9 \%$ of them declared to choose to continue their pregnancies.

Conclusion: The results of our study revealed that the level of knowledge about prenatal diagnostic tests in Gaziantep is low and it is necessary to plan large-scale education programs in order to ensure that women can have a healthier pregnancy.

Keywords: Questionaire, Awareness, Prenatal diagnosis 


\section{Gíriş}

Prenatal (doğum öncesi) tanı, fetüs veya embriyodaki konjenital anomalilerin ve genetik bozuklukların erken dönemde teşhis edilmesi işlemidir. Popülasyonda genetik ve/veya çevresel nedenlerle, konjenital anomalisi olan bir çocuk sahibi olma riski, \%3 ile \%5 arasında değişmektedir (Bozzette, 2002). Konjenital anomalilerin büyük bir kısmını kromozomal anomaliler oluşturur ve bunlar genellikle tedavi edilemeyen patolojilerdir. Bu tür hastalıklar aile ve toplumu sosyoekonomik yönden olumsuz etkiler. Erken gebelik döneminde bunların belirlenmesi ve etik/yasal değerler kapsamında gebeliğin sonlandırılması prenatal tanı çerçevesinde incelenir. Günümüzde, biyokimyasal/sitogenetik/moleküler sitogenetikyöntemler ve ultrason görüntüleme teknolojisindeki gelişmeler sonucunda, ilk trimester tarama testleri (nukaltranslusensi, free B-hCG, PAPP-A), ikinci trimester tarama testleri (üçlü ve dörtlü tarama testleri) ve maternal kanda fetal DNA'nın tespitine dayanan test (Noninvaziv prenatal tarama testi-NIPT) gibi prenatal tanıya yönelik testlerin kullanımı artmış ve bu sayede daha yüksek oranda fetalkromozomal anomali tespiti yapılabilir duruma gelinmiştir (Crane ve ark., 1988; Lo ve ark., 1997; Chiu ve Lo, 2011). Fetalkromozomal anomaliyi değerlendirmek için riskli gebelerde kesin tanı konulabilmesi için ilk trimesterdekoryonvillus örneklemesi (CVS) ve erken amniyosentez, ikinci trimesterdeamniyosentez veya daha ileri haftalarda kordosentez gibi invaziv prenatal tanı yöntemleri uygulanabilmektedir. Prenatal tanı endikasyonları; maternal yaşın 35'in üzerinde olması, kromozomal anomalili doğum öyküsü veya eşlerde ya da ailede kromozomal anomali bulunması, ultrasonda anöploidi düşündüren bulgular, pozitif üçlü test, nukaltranslusenside artış ve maternalanksiyetedir (Beksaç, 1996).

Doğum öncesi dönemde fetüse ait hastalıkların ve doğumdan sonra bebekte müdahale gerektiren durumların öğrenilmesi, bu duruma karşı müdahaleyi mümkün kılmaktadır (Stembalska ve ark., 2007). Bu testler sonrası tespit edilen anomalilerin ciddiyeti göz önüne alınarak, doğum öncesi ve sonrası tedavi olasılıkları belirlenebilmekte ayrıca anne-baba adayları zihinsel/fiziksel ano- malili bebeği olacağını öğrendiğinde etik/yasal değerler çerçevesinde gebeliğin sonlandırılmasını isteyebilmektedir (Sandelowski ve Barroso, 2005; Potur ve ark., 2009; Berceanu ve ark., 2014).

Bu çalışma ile Gaziantep'te gebelerin prenatal tanı testleri hakkında bilgi, farkındalık düzeylerini ve bu konudaki tutum, davranışlarını araştırmak amaçlanmıştır.

\section{MATERYAL VE METOT}

Araştırmaya SANKO Üniversitesi Sani Konukoğlu Hastanesi Uygulama ve Araştırma Merkezi, Kadın Hastalıkları ve Doğum Polikliniğine rutin gebelik takibi amacryla başvuran 500 gebe dâhil edildi. Araştırmanın amac1 katılımcılara açıklandı ve kabul edenlere yüz yüze görüşme tekniği ile alanında uzman bir Öğretim Üyesi kontrolünde, Tıp Fakültesi öğrencileri tarafından anket uygulandı. Araştırma için üniversitemizin Klinik Araştırmalar Etik Kurulundan onay alındı (2016/01/02) ve anketler Eylül 2016-Eylül 2017 tarihleri arasında uygulandi.

Anket dört bölümden oluşmaktaydı: (1) demografik veriler ve sosyal geçmiş; (2) kadınların üreme özellikleri; (3) prenatal tanı testlerinin farkındalığını değerlendirmek için bir dizi soru (4) kadınların prenatal tanı testlerine yaklaşımlarını ve anomalili bir çocuğa sahip olma durumunu kabullenmelerini değerlendirme yönelik sorular. İstatistiksel analizler için IBM SPSS Statistics 23 programı kullanıldı. Tanımlayıcı istatistik olarak ortalama ve standart sapma, yüzde ve sıklık verildi. Karş1laştırmalar için ki-kare testi kullanıldı ve $\mathrm{p}<0.05$ anlamlı olarak kabul edildi. Çalışmamız SANKO Üniversitesi Tıp Fakültesi öğrenci bilimsel araştırma projeleri uygulaması (PRJ 2016) çerçevesinde desteklenmiştir.

\section{BULGULAR}

Çalışmaya katılan gebelerin tanıtıcı özelliklerine göre dağılımları Tablo 1'de verildi. Katılımcıların eğitim düzeyine göre gebelik takibine gitme durumları arasında istatistiksel olarak anlamlı bir fark tespit edilmemiştir ( $>0.05)$ (Tablo 2). Prenatal tarama testlerinden birini (ikili/üçlü/dörtlü tarama) yaptırdığını bildiren katılımcı oranı yalnızca \%36.1 ( $\mathrm{n}=180)$ olduğu belirlenmiş ve yaptıranların da \%3.3'ünün ( $\mathrm{n}=6)$ sonucunun anormal olduğunu belirtilmiştir. Prenatal tanı testleri ile ilgili ge- 
belerin verdiği cevaplar ise Tablo 3'de verilmiştir. Daha önce prenatal tanı testlerinden birini yaptıran katılımcı oranı sadece \%4.4 (n=22) iken, \%17.2'si $(n=86)$ daha önce prenatal tanı testlerini duyduğunu ve hangi durumlarda yapıldığını bildiğini belirtmiş, bildiğini söyleyen 86 kişinin \%65.4'ünün ( $n=53)$ doğru bilgiye sahip olduğu tespit edilmiştir. Katılımcıların eğitim düzeyine göre prenatal tanı testlerinin endikasyonlarını bilme durumları arasında istatistiksel olarak anlamlı bir fark tespit edilmiştir $(p=0.006)$ (Tablo 2). Eğitim düzeyine göre ikili karşılaştırma yapılarak Bonferroni düzeltmeli p değeri 0.017'ye göre değerlendirildiğinde okuryazar/ilköğretim ve lise mezunları arasında fark bulunmamıştır $(\mathrm{p}=0.045)$, okuryazar/ilköğretim ve üniversite mezunları arasında anlamlı fark elde edilmiştir ( $p=0.002$ ). Eğitim düzeyi lise ve üniversite olanların ise prenatal tanı endikasyonlarını bilmeleri bakımından aralarında istatistiksel fark bulunmamıştır ( $\mathrm{p}=0.354)$.

Doktorlarının prenatal tanı testlerinden birini önermesi hâlinde \%9.9'u (n=49) yaptırmamayı tercih edeceklerini ifade etmiştir. Katılımcıların yaptırmamayı tercih etmelerinin nedenleri Tablo 3'de detaylı bir şekilde verilmiştir. Bebeklerinde genetik olarak bir kusur tespit edilmesi hâlinde \%82.9'u (n=413) gebeliklerine devam etmeyi seçeceklerini belirtmiştir. Eğitim düzeyi ile bebekte bir kusur belirlenmesi durumunda gebeliği sonlandırma kararı istatistiksel olarak fark göstermiştir. Bonferroni düzeltmeli $\mathrm{p}=0.017$ düzeyine göre okuryazar/ilköğretim ve lise mezunları ile lise ve üniversite mezunları arasında fark bulunmamıştır ( $\mathrm{p}=0.075$; $\mathrm{p}=0.043$ ). Ancak okuryazar/ilköğretim ve üniversite mezunları arasında fark tespit edilmiştir $(\mathrm{p}<0.001)$ (Tablo 2). Katılımcıların kendisinin ve/veya eşinin ailesinde, Down sendromlu birey varlığı oranı \%4.2 (n=21) olarak belirlenmiştir. Araştırmamıza katılan kadının veya eşinin ailesinde Down sendromlu bireyin olması ile bebekte bir kusur belirlenmesi durumunda gebeliği sonlandırma kararı arasında anlamlı bir ilişki tespit edilmiştir ( $p=0.043$ ). Ailesinde Down sendromlu birey olan katilimcilardan \%33.3'ü, olmayan katılımcılardan ise \%16.4'ü gebeliği sonlandırmayı tercih edeceğini belirtmiştir.

\section{TARTIŞMA}

Prenatal tanının amacı; gebeliğin etik açıdan sonland1rılmasına uygun olduğu dönem içerisinde, fetüste çeşitli genetik hastalıkların bulunup bulunmadı̆̆ını ortaya koymaktır. Gebelik haftası ilerledikçe anne ile fetüs arasındaki bağ kuvvetlenmekte ve anne bebeğini daha çok benimsemektedir. Dolayısıyla fetüste gebeliği sonlandırmayı gerektirecek genetik bir bozukluğun, mümkün olan en erken dönemde tespit edilmesi önem taşımaktadir (Bilen ve ark., 2015). Bu nedenle gebelerin prenatal tanı yaptırmaları sosyolojik ve psikolojik açıdan oldukça önemli bir karadır. Bu süreçte uzmanların ortaya çıkabilecek sonuçlar hakkında doğru ve tarafsız bilgi sağlaması, hastaların ise bu sonuçları kendi değerleriyle uyumlu kılarak seçim yapmaları gerekmektedir (Marteau ve ark., 2001; Bekker, 2003).

Yapılan araştırmalar prenatal tanı testlerinin farkındalığının ve kullanımının ülkeler arasında değişiklik gösterdiğini ortaya koymuştur. İnanç, din, ırk, sosyoekonomik durum, eğitim düzeyi ve medeni durum gibi pek çok faktör kadınların bilgi ve tutumlarını etkilemektedir (Kuppermann ve ark., 1996; Suriadi ve ark., 2004). Ayr1ca gebelerin tercihlerinde; düşük yapma riskleri ve sonlandırma ile ilgili bilgi düzeyleri ve Down sendromlu bir bebeğe sahip olma ihtimali gibi değerlerin de etkili olduğu gösterilmiştir (Heckerlink ve Verb, 1991; Halliday ve ark., 2001). Bu nedenlerle bu konuda yapilan gebelerin bilgi ve farkındalık düzeylerini ölçmeye dayalı çalışmalar oldukça önemlidir.

Pirdal ve arkadaşlarının 315 anne adayı üzerinde yaptığı bir çalışmada gebelerin, gebelikle ilgili (fizyolojik değişiklikler, beslenme, izlem) bilgilerinin orta ve iyi düzeyde olduğu tespit edilmiştir (Pirdal ve ark., 2016). Bizim çalışmamızda benzer şekilde gebelik esnasında sigara kullanımının çok az olması, alkol ve uyuşturucu kullanımının hiç olmaması ve katılımcıların büyük çoğunun en az ayda bir kez doktor kontrolüne gitmesi bu verileri destekler niteliktedir. Çalışmamızda aynı zamanda eğitim düzeyi arttıkça düzenli doktor kontrolüne gitme oranı arasında anlamlı bir fark izlenmemesi de bölge halkının bu konudaki hassasiyetini göstermektedir. 
Çalışmamıza katılan gebelerin ortalama gebelik haftası 24.1 \pm 10.5 olmasına karşın rutinde uygulanan prenatal tarama testlerinden birini yaptırdığını bildiren katılımcı oranının oldukça düşük olması; katılımcıların bu testlerden birini yaptırmadığını ya da yaptırdığını ancak neden yaptırdığını bilmediklerini düşündürmüştür. Prenatal tanı testlerini hiç duymadığını belirten katılımcı oranının da oldukça yüksek olduğu tespit edilmiştir (\%82). Bu durum katılımciların hem prenatal tarama ve hem de prenatal tanı testleri hakkında bilgilerinin yetersiz düzeyde olduğunu göstermektedir. Katılımcılardan eğitim düzeyi ile prenatal tanı endikasyonlarını bilmeleri arasında anlamlı bir fark tespit edilmiştir. Çalışmamızın sonuçlarına benzer şekilde, Yunanistan'da yaşayan gebe kadınlar üzerinde yapılan bir çalışmada, prenatal tanı yöntemleri hakkında bilgi ve tutumları değerlendirmiştir (n=354). Yükseköğretim eğitim düzeyindeki gebelerin doğum öncesi tanı prosedürleri konusunda bilgi seviyelerinin ortalama iki kat daha yüksek olduğu bildirilmiştir (Kitsiou-Tzeli ve ark., 2010). Ayrıca çalışmamızda doktoru prenatal tanı testlerinden birini önerirse yaptırmayacağını bildiren gebelerin büyük bir kısmi, yaptırmama nedeni olarak eşinin izin vermeyeceğini göstermiştir (\%20.4). Prenatal tanı testlerinin farkındalığını ve yaklaşımları değerlendirmeye yönelik yapılan çalışmalarda genellikle gebelerin eşlerinin araştırmaya dâhil edilmediği görülmüştür. Ancak prenatal testlerle ilgili kararlar tercihen her iki eş tarafından verilir ve araştırmalar, erkeklerin bu karar verme sürecine katılmak istediklerini göstermiştir (Draper., 2002).

Erkeklerin dâhil edildiği bir çalışmada, kadın ve erkekler arasında prenatal testler ile ilgili bilgi düzeyleri ve bu testlere karşı gösterilen tutumlarda anlamlı bir fark bulunmadığı ve bilgi düzeylerinin oldukça iyi olduğu belirtilmiştir. Bu çalışmada hem kadın hem de erkek katılımcıların çoğunluğu yüksek eğitim seviyesine sahiptir (van Schendel., 2014). Bu sonuçlar kadın/erkek tüm toplumun eğitim düzeyinin arttırılması ile bu konudaki bilgi düzeylerinin de artacağını düşündürmektedir.

Çalışmamıza katılan gebeler oldukça yüksek bir oranda prenatal tanı testleri sonucunda endikasyon olsa bile gebeliklerini sonlandırmak istemedikleri belirtmişlerdir (\%82.9). Eğitim düzeyi ile bebekte bir kusur belirlenmesi durumunda gebeliği sonlandırma kararı farklılaşmaktadır; üniversite mezunları okuryazar/ilköğretim mezunlarına göre daha fazla oranda gebeliği sonlandırma kararı alacağını bildirmiştir. Başka bir çalışmada, intrauterin dönemde fetüse ait herhangi bir anomali saptand1ğında, ailelerin genellikle gebeliğin sonlandırılması yönünde eğilim gösterdiği tespit edilmiştir (Dölen ve ark., 2003). Manisa'da 518 kadına erken postpartum dönemde uygulanan bir anket çalışmasında; kadınların \%12'si, bebekte bir kusur belirlenmesi durumunda gebeliğin sona erdirilmesini tercih edeceklerini söylerken, \%34.9'u gebeliğin sonlandırılmasını kabul etmeyeceklerini ve doğum yapmayı tercih ettiklerini belirtmiştir. Ayrıca kadınların üçte biri (\%29.9) doktorun kendileri için bir karar vermesini ve \% 23.2'si Down Sendromlu bir çocuğa sahip olabileceğinden emin olmadığını bildirmiştir (Yanikkerem ve ark., 2012). Kırşehir'de 222 gebe üzerinde yapılan bir çalışmada ise "invaziv tahliller sonucunda bebeğinizin özürlü olduğu anlaşırsa bebeğinizi doğurmak ister misiniz?" sorusuna \%56.8 oranında evet, \%43.2 oranında hayır cevabı alınmıştır (Karakuş, 2015). Suudi Arabistan'da yapılan 2761 kadının yer aldığı bir çalışmada ise, katılımcıların \%17'si gebeliğin sonlandırılmasının kabul edilemez olduğunu, \% 33'ü kabul edilebilir olduğunu ve \% 30'u belirli koşullar altında kabul edilebilir olduğunu belirtmişlerdir. Katılımcıların çoğu gebeliğin sonlandırılmasını kabul edilebilir olduğunu düşünmesine rağmen, kabullerini İslami kürtaj düzenlemeleri yapılacak şekilde koşullandırmışlardır (AbdulAzeez ve ark., 2019). Gebeliğin sonlandırması konusundaki en belirleyici faktör dini inanışlardır (Alkuraya ve ark., 2001). Ayrıca farklılıkların başta katılımcıların eğitim düzeyi olmak üzere araştırmanın yapıldığı bölge ve kültürel farklar gibi nedenlerden kaynaklandığı düşünülmektedir.

Toplumda en çok bilinen genetik hastalıklardan olan Down sendromlu bir çocuğa sahip olmak ebeveynlere; çocukları büyüdükçe ona sunacağı eğitim, çocuğunun iş ve meslek edinme durumu, ebeveynlerin ölümü sonrasında ne olacağı düşüncesi gibi kaygıları da beraberinde getirmektedir (Karadağ, 2014). Şüphesiz ki bu tür kaygıları Down sendromlu bireyler ile bire bir yaşamış, ailesinde Down sendromu olan kişiler daha iyi anlaya- 
bilmektedir. Bu durumun bir yansıması olarak; araştırmamıza katılan kadının veya eşinin ailesinde Downsendromu olan bireyin olması ile bebekte bir kusur belirlenmesi durumunda gebeliği sonlandırma kararı arasında anlamlı bir ilişki tespit edilmiştir.

Toplum sağlığı ve koruyucu hekimlik adına oldukça önemli olan prenatal tanı çalışmalarında öncelikle kromozomal anomali risk faktörlerinin bilinmesi ve bu faktörlere bağlı olarak fetüsün etkilenme olasılığının belirlenmesi gereklidir. Prenatal tanı testlerin yapılması ve sonrasında gebeliğin akıbeti ile ilgili olarak etik ilkeler doğrultusunda anne ve baba adayının özerkliğine saygı duyarak kendi seçimlerinin yapmalarını ve en yararlı uygulamayı seçmeleri sağlanmalıdır (Koçak ve ark., 2015). Tüm bu ilkeler göz önüne alındığında anne ve baba adaylarının bilgi ve farkındalık düzeyi önem kazanmaktadır. Ancak araştırmamızın yapıldı̆̆ı yer olan Gaziantep göz önüne alındığında bu konuda önemli bir eksiklik olduğu dikkati çekmektedir. Prenatal tanı testleri hakkında gebelere doğru danışmanlık verilmesinde sağlık profesyonellerine büyük iş düşmektedir.

Bu konuda Bulgaristan'da yapılan bir çalışmada, 500 kadına farklı tarama ve tanı testlerinin farkındalığının değerlendirilmesine yönelik sorular yöneltilmiştir. Kadınların 384'ü (\%76.3) kadın doğum uzmanları tarafından bilgilendirildiklerini ve 345'i (\%68.5) bu bilgilendirmeden tatmin olduklarını belirtmişlerdir. Ancak NIPT testi sorulduğunda katılımcıların 202'sinin (\%40.2) NIPT'nin ne olduğunu bilmedikleri saptanmıştır. Bu durumun biyokimyasal tarama testlerinin, NIPT'den çok daha uzun zamandir uygulanıyor olması ve gebe kadınların büyük çoğunluğu tarafından kabul görür olmasından kaynaklandığı düşünülmüştür (Levkova ve ark., 2018) Bizim çalışmamızda da bu düşünceden yola çıkarak ve aynı zamanda anketin uygulandı̆̆ı bölgede NIPT'nin yaygın olarak kullanılmamasından dolayı bu tarama testi ile ilgili soru yer almamaktadir.

Sonuç olarak, çalışmamız gebelerin prenatal tanı testleri hakkında bilgi ve farkındalık düzeylerinin Gaziantep'te oldukça düşük olduğunu göstermiştir. Prenatal hizmet sunumlarında ebeveynlerin beklenti ve memnuniyetlerinin sürekli ölçülerek sürecin değerlendirilmesi ve bu doğrultuda iyileştirilmesi, ebeveynleri bilgilendirmek için hastanelerde eğitim programlanması ve yürütülmesi, riskli gebelik süreçlerinde aile odaklı hizmetlerin aktifleştirilmesi, danışmanlık süreçleri ile ilgili broşür/afiş hazırlanması ve bunların kitle iletişim araçları ile ailelere ulaştırılmasının gerekli olduğu düşünülmektedir.

\section{Çıkar Çatışması}

Yazarlar çıkar çatışması olmadı̆̆ını beyan eder.

\section{KAYNAKLAR}

AbdulAzeez S, Qahtani NHA, Almandil NB, Al-Amodi AM, Aldakeel SA, Ghanem NZ et al. Genetic disorder prenatal diagnosis and pregnancy termination practices among high consanguinity population, SaudiArabia. Sci Rep 2019;9(1):17248.

Alkuraya FS, Kilani RA. Attitude of Saudi families affected with hemoglobinopathies towards prenatal screening and abortion and the influence of religious ruling (Fatwa). Prenat Diagn 2001;21:448-51.

Bekker HL. Genetic testing: facilitating informed choices. In Encyclopaedia of the Human Genome, Cooper DN, Thomas N (eds). Nature Publishing Group-Macmillan Publishers Ltd: New York; 2003;926-930.

Beksaç MS. Fetal Tıp; Prenetal Tanı. Ankara, Medical Network, 1996: 29 -38.

Berceanu C, Albu SE, BoT, M, Ghelase MS. Current principles and practice of ethics and law in perinatal medicine. Curr Health Sci J 2014;40(3):162-9.

Bilen E, Yüksel M, Sezik M, Köse SA, Tola EN. Chorionvillus sampling for karyotyping at 11-14 weeks of gestation: evaluation of 42 cases. SDÜ Sağ Bil Derg 2015;6(1):1-3.

Bozzette M. Recent advances in prenatal screening and diagnosis of genetic disorders. AACN Clin Issues 2002;13(4):501-10.

Chiu RW, Lo YM. Non-invasive prenatal diagnosis by fetal nucleic acid analysis in maternal plasma: the coming of age. Semin Fetal Neonatal Med 2011;16(2):88-93.

Crane JP, Beaver HA, Cheung SW. First trimester chorionic villus sampling versus midtrimester genetic 
amniocentesis. Preliminary results of a controlled prospective trial. Prenat Diagn 1988;8(5):355-9.

Dölen İ, Özdeğirmenci Ö. Viabilite altı gebeliklerin sonlandırılması ve etik. Kadın Doğum Derg 2003;2:91-2.

Draper J. It's the first scientific evidence: men's experience of pregnancy confirmation. J Adv Nurs 2002;39: 563-70.

Halliday JL, Warren R, McDonald G, Rice PL, Bell RJ, Watson LF. Prenatal diagnosis for women aged 37 years and over: to have or not to have. Prenat Diagn 2001;21(10):842-7.

Heckerling PS, Verp MS. Amniocentesis or chorionic villus sampling for prenatal genetic testing: a decision analysis. J Clin Epidemiol 1991;44(7):657-70.

Karadağ G. Özel gereksinimi olan çocuğa sahip ebeveynlerin yaşadığı zorluklar ve çözüm önerileri. TAF PrevMedBull 2014;13(6):491-4.

Karakuş R. Gebelerin ikili ya da üçlü testler hakkındaki bilgi düzeyinin araştırılması. Jinekol Obstet Neonatol Tip Derg 2015;12(5):174-8.

Kitsiou-Tzeli S, Petridou ET, Karagkiouzis T, Dessypris N, Makrithanasis P, Sifakis S et al. Knowledge and attitudes towards prenatal diagnostic procedures among pregnant women in Greece. Fetal Diagn Ther 2010;27(3):149-55.

Koçak DY, Beji NK, Duman NB. Prenatal Tanı Yöntemlerinde Etik Yaklaşım. GOP Taksim E.A.H. JAREN 2015;1(2):86-90.

Kuppermann M, Gates E, Washington AE. Racial-ethnicdifferences in prenatal diagnostic test use and outcomes: preferences, socioeconomics, orpatient knowledge? Obstet Gynecol 1996;87(5 Pt 1):675-82.

Levkova M, Hachmeriyan M, Miteva V, Stoyanova M, Tsvetkova M, Konstantinova D et al. Women's awareness towards prenatal down syndrome tests in Bulgaria. JDSCA 2017;3(1):1-4.
Lo YM, Corbetta N, Chamberlain PF, Rai V, Sargent IL, Redman CW et al. Presence of fetal DNA in maternal plasma and serum. Lancet 1997;350(9076):485-7.

Marteau TM, Dormandy E, Michie S. A measure of informed choice. Health Expect 2001;4(2):99-108.

Pirdal H, Yalçın BM, Ünal M. Knowledge levels of pregnants on their pregnancy and the related factors. Türk Aile Hek Derg 2016;20:7-15.

Potur CD, Yiğit F, Bilgin ÇN. Anne adaylarının fetal sağlığı değerlendiren testlere yaklaşımının kalitatif incelenmesi. Maltepe Üniv Hemşire Bilim Sanat Derg 2009;2(3):80-92.

Sandelowski M, Barroso J. The travesty of choosing after positive prenatal diagnosis. J Obstet Gynecol Neonatal Nurs 2005;34(3):307-18.

Stembalska A, Slezak R, Pesz K, Gil J, Sasiadek M. Prenatal diagnosis-principles of diagnostic procedures and genetic counseling. FOLIA Histochem Cytobiol 2007;45 Suppl1:S11-6.

Suriadi C, Jovanovska M, Quinlivan JA. Factors affecting mothers' knowledge of genetic screening. Aust NZJ Obstet Gynaecol 2004;44(1):30-4.

vanSchendel RV, Kleinveld JH, Dondorp WJ, Pajkrt E, Timmermans DRM, Holtkamp CA et al. Attitudes of pregnant women and male partners towards non-invasive prenatal testing and widening the scope of prenatal screening. Eur J Hum Gene 2014;22(12):1345-50.

Yanikkerem E, Ay S, Ciftçi AY, Ustgorul S, Goker A. A survey of the awareness, use and attitudes of women towards Down syndrome screening. J Clin Nurs 2012; 2(11-12):1748-58. 